\title{
Accounting and Accountability in Fiji: A review and synthesis
}

\author{
Umesh Sharma \\ Department of Accounting \\ Waikato Management School \\ PB3105, Hamilton, \\ New Zealand. \\ Phone +64-7-8384247 \\ E mail: ups@waikato.ac.nz
}




\title{
Accounting and Accountability in Fiji: A review and synthesis
}

\author{
$\underline{\text { Abstract }}$ \\ This paper reviews accounting and accountability research in Fiji. The review is based on 41 \\ papers which were published in accounting refereed journals, professional journals, edited book \\ chapters and thesis and other refereed journals outside accounting. The reviews are over the \\ years 1978 and onwards. In addition to categorization of the reviewed papers according to \\ accounting topics, theories and methods of data collection, some themes to which the papers \\ could be related are discussed. Financial reporting/ accountability research is the most popular \\ research in Fiji followed by the new public management. Corporate governance research treads \\ third. \\ The paper findings suggest some directions for future accounting history research in Fiji and \\ where the data can possibly be sourced for such research. We conclude that more future work is \\ needed in the areas of accounting history which entails topics such as accounting and the state, \\ performance auditing, indigenous accounting, financial reporting, SMEs and accountability in \\ general.
}

Key words: Accounting, new public management, corporate governance, accounting standards, Fiji. 


\section{Accounting and Accountability in Fiji: A review and synthesis}

\section{Introduction}

The literature on Fijian accounting studies has received increasing interests in the recent years (Davie, 2000a, 2000b; Sharma et al., 2010, 2012; Alam et al., 2004; Irvine \& Deo, 2006). As there has been growing interest in this country specific accounting literature, it is timely for taking stock of them as yet acquired knowledge. This paper aims to review the literature on accounting and accountability in Fiji. This review can be relevant to both practitioners and accounting history researchers. Practitioners such as accountants, politicians, managers and consultants in Fiji can benefit as the paper can provide them avenues for improving their practice and better understanding Fijian accounting environment. Accounting history researchers may be motivated to tackle under researched areas in Fiji in their research endeavours.

Less Developed Countries accounting research, in general has been reviewed extensively (Hopper et al., 2009; Alwattage et al., 2007). However, there has been little attempt to review a country specific literature on LDCs. This paper attempts to fill this gap by reviewing the accounting and accountability literature in the Fijian context. The domain of our review have been largely on the refereed accounting and management journals such as Accounting Auditing and Accountability Journal, Critical Perspectives on Accounting, Accounting History, Journal of Pacific Studies, Pacific Accounting Review, International Journal of Economics and Accounting, International Journal of Critical Accounting, The International Journal of Public Sector Management and Australian Accounting Review amongst others. We also relied on edited book chapters and thesis. Our review covers papers that were published from 1978 onwards. We categorise the reviewed papers according to the themes. Some of the themes that emerged from the literature are new public management, financial reporting/accountability and corporate governance.

The remainder of the paper is structured as follows. Section 2 addresses the design of the reviews. Section 3 set out the categorization of the reviewed papers. Section 4 is the core of the review and it aims to show what we know about Fiji's accounting and accountability literature with an emphasis on the three indicated themes above. These themes entail new public management, financial reporting/ accountability and corporate governance. The paper finally presents the conclusions of the review and gives pointers for future accounting history research agenda on Fiji in section 5. 


\section{Review Design}

Our review focuses on the accounting literature from Fiji sourced from journal articles, edited book chapters and thesis. Because we aim to take stock of the academic research on accounting in Fiji, our review concentrates mainly on papers published in international academic journals. However, we also review a few edited book chapters and thesis. This resulted in a pre-selection of journals such as Critical Perspectives on accounting, Accounting, Auditing and Accountability Journal, Accounting History, Australian Accounting Review, Journal of Accounting and Organizational Change, Pacific Accounting Review, International Journal of Economics and Accounting amongst others.

Our steps in the selection of journals and papers followed a 'snowball method' in the sense that papers selected in some core international academic journal hinted additional papers which came from other accounting and public administration journals such as International Journal of Public Sector Management, Asian Review of Accounting, Fijian Studies: A Journal of Contemporary Fiji, Fiji Accountant, Financial Reporting Regulation and Governance. The research focuses on papers that have been published over the years 1978 and onwards.

Three themes were identified which is used as an interpretation of the findings of the reviewed papers. The themes have been selected because they are relevant for further knowledge development and/ or are seen as contested. The three themes that emanated from the literature are new public management, financial reporting/accountability and corporate governance.

Our approach in reviewing academic papers on accounting research in Fiji can be derived as follows. The selected papers for review- 41 in total- have been read and summarized by the author. Each paper summary also includes categorizations for topics, theories and methods of data collection. Moreover, its main findings are briefly indicated. This categorization is shown in Appendix $\mathrm{A}$ in the paper and the access to paper summaries aim to make the review controllable and repeatable by interested authors.

The next step in our approach regards the use of appendix A for drafting tables of the various categorizations, which is presented in Section 3. 


\section{Categorizations of the reviewed papers.}

This section presents the categorization of the reviewed papers according to accounting topics, theories and method of data collection. Table 1 presents the categorization of the papers according to the accounting topics.

Table 1 Categorisation of papers according to accounting topics

\begin{tabular}{|l|l|l|}
\hline Accounting Topics & Number of Papers & As a percentage of total \\
\hline New public management & 14 & 34 \\
\hline $\begin{array}{l}\text { Financial Reporting/ } \\
\text { Accountability }\end{array}$ & 21 & 51 \\
\hline Corporate governance & 3 & 7.5 \\
\hline Other & 3 & 7.5 \\
\hline Total & 41 & 100 \\
\hline
\end{tabular}

The table shows that a greater research has been done in the area of financial reporting and accountability (51\%). The new public management reform is the second area well researched in Fiji at $34 \%$. Corporate governance research has attracted some interest but is relatively low at $7.5 \%$. The remaining papers that could not fit the above three categories were at $7.5 \%$ and covered areas such as accounting education, sustainability accounting and colonization.

Table 2 presents the categorization of the reviewed papers according to the theories used for explaining accounting phenomena.

Table 2: Categorization of papers according to theories

\begin{tabular}{|l|l|l|}
\hline Theories & Number of papers & As a percentage of total \\
\hline Institutional theory & 7 & 17 \\
\hline Critical theory & 4 & 10 \\
\hline Social theory & 6 & 15 \\
\hline Remaining theory & 4 & 10 \\
\hline No explicit theory & 20 & 48 \\
\hline Total & 41 & 100 \\
\hline
\end{tabular}

We can observe that $48 \%$ of the papers did not adhere to any theory. Rather they utilized literature to inform their study. The most popular theory was institutional theory (17\%), followed by social theory at $15 \%$. Critical theory is the next utilized theory at $10 \%$. The remaining theory accounted for $10 \%$ of the papers. The remaining theory encompassed theories 
such as diffusion of innovation theory, theory of aesthetics of ambiguity and Laughlin's (1991) theory of first-order and second-order change.

Finally, Table 3 shows the categorization of the reviewed papers according to the methods of data collection used. Two findings are highlighted. First, case-field research is the most common used method of data collection (51\%), while the research based on archival data (30\%) and survey (12\%) are relatively scarce. Relatively more studies need to be done using research methods of surveys, literature review and policy studies based on official documents.

Table 3: Categorisation of papers according to the methods of data collection

\begin{tabular}{|l|l|l|}
\hline Method of data collection & Number of papers & As a percentage of total \\
\hline Literature review & 2 & 5 \\
\hline Case-field study & 21 & 51 \\
\hline Survey & 5 & 12 \\
\hline Archival Data studies based on & 12 & 30 \\
\hline $\begin{array}{l}\text { Policy } \\
\text { official documents }\end{array}$ & 1 & 2 \\
\hline Total & 41 & 100 \\
\hline
\end{tabular}

\section{Taking stock of acquired knowledge}

This section presents the review findings according to the themes identified in the introductory section of the paper. It subsequently deals with new public management (section 4.1), financial reporting and accountability (section 4.2) and corporate governance (section 4.3). Finally, some remaining papers which could not be attributed to each of the above indicated themes are briefly discussed (section 4.4).

Rather than critically analyzing the reviewed papers in accordance to the way the findings have been informed by the theory or the appropriateness of certain methods for answering particular research questions, we aim to present the main findings related to the research goals of the reviewed papers. In section 5, we take an evaluative approach and identify potential future research possibly on accounting history in Fiji. This is informed by gaps in the available research. 


\subsection{New Public Management}

The introduction of new public management (NPM) involves the introduction of economic rationality into the public sector and use of business-like styles and instruments such as accounting (Sharma et al., 2012). These reforms have been advocated in Fiji by international donor organization such as the World Bank, Asian Development Bank and the International Monetary Fund. As the academic community raises some doubts about the wholesale application of reforms in Fiji, some authors argue that what has been adopted in Fiji is a modified version of new public management that aligns with the cultural and social aspects of the Fijian society. This issue may require further investigation by researchers. The ensuing paragraphs will take stock of what is known in the NPM reforms in the literature in Fiji.

Sharma, Lawrence and Fowler (2012) investigate tension between the implementation of new public management and associated accounting technologies in the Fiji telecommunication sector and the indigenous Fijian culture and political structure. In the Fiji telecommunications company, the cultural conflicts and political influences led to the new public management process being resisted and modified to reduce the tension between economic and social relations. The research aim is achieved by focusing on archival documents and interviews with those involved in Fiji telecommunications.

Davie's (2004) research extends race research in accounting through the experiences of a recently corporatized state owned enterprise in Fiji: Fiji Pine limited. Her research shows how the financial restructuring of the Pine industry in Fiji assumes hegemonic and exclusive strategy ostensibly to indigenize all pine afforestation activities. The Indo-Fijian population was excluded from participating in the pine industry as it was reserved for indigenous Fijian only by the state. Davie reports that the use of accounting language in constructing the reality of forestry activities is not compatible with the tradition of the community in which it was imposed. Communal expectations and obligations overrode capitalist technologies in the field study. Davie (2000a) examines the same Fiji Pine Limited based on her experience of living in the pine forest villages as a researcher. She utilizes theoretical notion of 'ambiguity' to interpret the case study. An 'ambiguous situation' may be defined as one in which an individual is unable to properly categorise due to insufficient information. The pine industry was established by the 
chiefly Alliance government that represented the hierarchical chiefly hegemony. There was conceptual incomprehensibility of accounting by land owners such as they could not understand the notion of profit, discounting, depreciation, and so on as that was alien to the Fijian culture.

Nandan and Alam (2004), in a case study of Fiji Development Bank point out how the introduction of a new profit-based significance structure in the 1990s replaced the old development based signification structure. The new signification structure was shaped by the political upheavals of 1987 coups, and increasing competition in business from the commercial banks. The profit-based structure provided the dominant language and meaning for actions and interactions within Fiji Development Bank. Alam et al., (2004) used Fiji Development Bank as a case study informed by Giddens structuration theory. They illustrate that the establishment of profit centres at branch level of the Fiji Development Bank and insistence on profit-driven, commercialised loans and repayment policies contrast with the communal culture of its indigenous people. The indigenous Fijian communal tradition is contradictory to capitalist development. 'Kerekere', the practice of borrowing amongst kin at the will of the borrower, works against the accounting entity and other related accounting concepts and conventions. 'Sole Solevaki' is yet another example of communal obligation that encourages indigenous Fijians to work together for the community as a whole, but remains contradictory to commercial principles. Many indigenous Fijian shops and co-operatives have been closed due to these customs which indigenous Fijians cannot forfeit. The tension between communal practices and commercial principles of operations mainly account for the above failures. Traditional indigenous culture is community based, while new public management is based on individualism and sanctity of profit. Therefore, there is potential tension between the indigenous culture and that of new public management.

Irvine and Deo (2006) present a study of the Fiji Development Bank that demonstrates how a different theoretical lens has on the selection and interpretation of events. The Western banks set up in Fiji had strong collateral requirements for borrowings which the indigenous community could not fulfil as the assets are held communally by them. The western banks, on the other hand, require individual ownership of assets. Thus, Fiji Development Bank was established for the indigenous Fijian to solve the issue of long-term financial assistance for agriculture. The Bank offered reduced interest rates and less onerous loan security requirements. However, not 
all loan schemes supported by the Fiji Development Bank have been successful. In the case of the special loan scheme for Fijians, established to encourage Fijians into commerce, contradictions emerged between the bank's written operating policies and traditional authority. Conflict arose between traditional Fijian values and beliefs about advancements on easy installments ('kerekere') and the commercial practice that regards profit as essential for survival. As a result, there are some write offs of loans as well. The Fijian culture promotes a lifestyle and set of values that do not encourage 'thrift, savings and capital accumulation', the heart of entrepreneurial, capitalist activity. Fiji Development Bank has faced with an enormous impossible task that of reconciling the profit motive with the cooperative culture of Fijians. The authors' interpretation through Weber's theory of rationality views that Fiji Development Bank's goal is achievable. Fiji Development Bank forgoes profits in the short tem in order to move towards longer term sustainability. The role of accounting has been enabling unlike the view from Marxist theory which views role of accounting as imposed and negative.

Lawrence et al., (2009) employ critical theorizing of institutional theory to show how the Housing Authority of Fiji's mission of providing housing to low income earners was obscured. The changes in Housing Authority of Fiji's accounting and management system came from pressure from donor agencies such as Asian Development Bank and the World Bank. The top management used power to implement commercial accounting and control systems. The consultants and people brought from the private sector to carry out changes towards business routines were 'carriers of change' at Housing Authority. Lawrence et al., (2009) found that the changes in the organisation systems resulted in the organisation losing sight of its original purpose which was to assist the underprivileged people who were locked out of the housing market place. Nath \& Sharma (2014) using the same case study of Housing Authority of Fiji examine the implementation of a performance management system. Their article draws on diffusion of innovation theory and explores the effectiveness of performance management. Nath and Sharma (2014) findings reveal that with growing pressure for commercialisation from donor agencies, the accounting and managerial practices seem to contradict the organisation's original purpose to provide housing needs for the poor. The performance management system played a role in enabling the commercial focus of Housing Authority of Fiji and moved the organisation moderately away from original non-commercial objectives. The research evidence indicated that 
there was a disconnect between the performance management system and its actual use. For example, there were profitability indicators when Housing Authority was continually making losses. However, the aim was for Housing Authority to continually improve its poor performance. The irony is that all the PMS changes that took place, though technically sound, did not improve the operational efficiency of Housing Authority. Instead, the efforts diverted the organisation from its original purpose of assisting those underprivileged people who were locked out of the Fijian Housing Authority.

Sharma and Hoque (2002) analyse the Housing Authority's total quality management implementation and consequences of total quality management implementation during the period of 1992 to 2000 . The authors obtained the data from semi structured interviews with nineteen employees throughout the organization along with internal documentary material from the organization. The authors found that the workers at Housing Authority were reluctant to the idea of total quality management implementation but through training this problem was mitigated. The implementation of total quality management was successful because the initiative was supported by top management and this acceptance filtered down through the organization. With the implementation of total quality management practices, the loans at Housing Authority was approved in quicker time frame and the employees adopted a greater customer focus.

Sharma and Lawrence (2005) examine the public sector reforms in Fiji and the introduction of market-oriented practices in the state Public Rental Board. The tensions between profit seeking and provision of public service are explicated. The empirical evidence is interpreted using new institutional sociology as well as the technical-rational perspective. The Public Rental Board implemented private sector business techniques such as economic rents, sale of state houses, and performance measurement in the form of the balanced scorecard. Such a business-like approach was demanded by international financial institutions such as the World Bank. In return for lending money, international financiers expect a more efficient, wealth producing economy. However, global trends in the form of imposed restructuring of the public sector do not necessarily meet local demands. Tensions are created between the mission and performance of the state rental organization charged with providing accommodation for the less fortunate in Fiji. The varied private sector measures obscured the original mission of housing the poor. The principal objective of providing accommodation for low and middle-income earners by the 
Public Rental Board has so far not been attained. Thousands of applicants are outstanding to be housed and the Public Rental Board is not in a position to provide an adequate supply of houses.

Sharma and Lawrence (2009) examine public sector reforms in Fiji. The paper examines the role accounting and control systems had on the reformation of two public sector organisations, the Housing Authority and Telecom Fiji Limited. The authors found that both Housing Authority and Telecom Fiji underwent directional changes to their control and accounting systems after the public sector reform. Sharma and Lawrence (2009) found that in Housing Authority, the change agents focused on making profit which overrode the organisations function to look after the welfare of poor Fijians who were locked out of the housing market. The major change occurred in Housing Authority when the organisation's operation was specified in financial terms. The new archetype reflected attitudes and behavior in the workforce in relation to commercial business routines. Sharma and Lawrence (2009) found that Fijian political and cultural forces were greater inhibitor to the change at Telecom Fiji in comparison to the Housing Authority. The authors conclude that both organisations have undergone changes that can be identified using Laughlin's (1991) framework of second-order change which is consistent with Laughlin's notion of 'colonization'.

Sharma and Lawrence (2008) study attempts to demonstrate that institutional theory encompass a processual explanation of change. The paper focuses on a case study of Fiji Posts and Telecommunications Limited and makes use of explanatory case study method. The paper found that changes to commercial norms by Fiji Post and Telecommunication Limited were slow and not widely accepted by everyone. The study explains that it was communitarian value and tribal obligations in forms of personal relationships to management that triggered a resistance to business routines from a public service routine. The senior management, over time, were instrumental in institutionalization of business routines. Sharma and Lawrence (2008) conclude that organizational change in Fiji needs to consider the cultural and political influences that may render resistance to change to business routines from a public service ethos. 
Sharma et al., (2010) examine the micro-process and practice changes that occur within Telecom Fiji due to the implementation of total quality management practice. The normative institutional pressure such as the consultants was instrumental in bringing total quality management practices within Telecom Fiji. Sharma et al., (2010) found that the total quality management implementation was perceived as being a continuous process which was replacing public sector templates with private sector templates. The $\mathrm{CEO}$ and the management team were instrumental in the adoption of total quality management practices as they were identified as being institutional entrepreneurs influencing the embedded agents (organizational workers) to adapt to total quality management routines. Through the total quality management practices, the business routines at Telecom Fiji were assimilated.

Summing up the findings on new public management in Fiji, we find the following issues seem to emerge from our review. First, the influence of international donor organisations on the new public management practices seems to be substantial. Cultural and political influences in Fiji can impede progress of the public sector reforms. The Fijian culture is one that believes in collectivism, and is not so much inclined towards individualism and thrift. Such cultural and local context can pose resistance to reforms in the public sector. The new public management reform has not been adopted in totality. Rather, a modified version of new public management has been adopted by the Fijian public enterprises. The next section reviews the literature on financial reporting.

\subsection{Financial reporting/ accountability}

This section reports about the literature on financial reporting and accountability in Fiji. Financial reporting and accountability is the most studied topic within the Fijian accounting literature.

The development of the Fiji Island's accountancy profession dates back to the 1940s when the government accepted a proposal to register tax agents (Chand, 2002). Chand (2002) states that at the same time, few of the practicing Fiji Islands accountants had recognized professional qualifications. Any person could open an accounting practice and publicly offer their services. Despite some pressure, the government did not introduce registration procedures for accountants. 
It was not until 1961 that the government realized the need for accountant registration. The Legislative Council subsequently approved the Public Accountants (Registration) Ordiance 1962 with effect from 1 July 1963. The Ordinance provided the establishment of the Public Accountants Registration Board, which comprised the Registrar and two other Governor appointed members (Chand, 2002). It also laid out the registration requirements. According to Chand (2002), to be registered Fiji Islands' accountants either had to meet the New Zealand Society of Accountants requirements or be a member of a New Zealand Society of Accountants recognized accountants association. The board had limited supervisory powers. According to Chand (2002), it was ineffective in developing the Fiji Islands' accountancy profession. Registered accountant numbers grew from just 13 in 1963 to only 40 by 1970 (Chand, 2002). In response, practicing accountants lobbied the government to establish a strong professional body that would not only control but also develop the profession. Therefore, at the request of the Public Accountants Registration Board, the government developed and passed the Fiji Institute of Accountants Act 1971. The Act provided for the Fiji Institute of Accountants establishment.

Chand and White (2007) examine the reasons for the willingness to accept IFRSs in Fiji. The authors demonstrate that in the process of convergence, the influence of the private interestsmultinational enterprises and large international firms can shape transfer of economic resources in their favour wherein the public interests are usually ignored. Chand and White (2007) make suggestions on how public interests might be best served within the current financial reporting system and how, in principle, the needs to report both globally and locally can be reconciled. The Fiji Institute of Accountants has adopted the IFRSs from 2007 onwards. According to Chand and White (2007), the accounting practices initially employed in Fiji were those imposed by the colonial power. They have been shaped by the trading patterns engendered under the aegis of the Commonwealth countries. These influences were further reinforced by the work of expatriate professional accountants and the establishment of the multinational accounting firms in Fiji (Juchau, 1978; Kapadia, 1980; Kukeraja, 1997). In particular, these expatriate accountants were responsible for establishing the professional institutes and the ethos of the accounting profession (Kukeraja, 1997). The accounting system in Fiji has been strongly influenced by the British and more recently by international arrangements and practices. Currently, the Fiji Institute of Accountants through its Accounting and Auditing Standards 
Committee promulgates accounting standards that serve as the basis for preparing the financial statements.

According to Chand and White (2007) in adopting the IFRS, the Fiji Institute of Accountants has ignored country specific issues such as the nature of industry, size of business enterprises and sophistication of the capital markets. In addition, the Fiji Institute of Accountants has ignored the needs of the local users of accounting information. For example, the indigenous Fijian population holds ownership of virtually all land and the economic resources found from coastal waters. A regulation, perhaps, requiring specific disclosure of rents paid for the use of these resources, which are collected and administered not by the landowners themselves, but the Native Land Trust Board, would enable the landlords to compare returns from those secured by other factors of production. Such disclosures would allow for better informed decisions between stakeholders in a reporting entity and hopefully more equitable and timely resolution of disputes. According to Chand and White (2007), no such regulation has been developed.

Chand and Patel (2008) note that in Fiji, the Companies Act (1983) and the pronouncements of the professional accounting body, the Fiji Institute of Accountants, provide the legal and regulatory framework for financial reporting in Fiji (Chand \& Patel, 2008). Authorised to operate as the sole professional accounting body in Fiji by virtue of an Act of Parliament (Fiji Institute of Accountants Act, 1986), The Fiji Institute of Accountants establish a by-law in 1986 in regards to formulation and promulgation of auditing and accounting standards in Fiji. According to Chand and Patel (2008), the by-law acknowledges the institute's obligation to support standards promulgated by the IASB and the International Federation of Accountants, and to use its best endeavours to ensure compliance.

The current Fiji Accounting Standards is almost exclusively predicated on the IFRS and constitutes twenty three mandatory standards and eleven 'guidance standards'. According to Chand and Patel (2008), the reasons for the issuance of the IFRSs as 'guidance standards' are twofold. First certain standards may be irrelevant to Fiji. Examples include IAS 29 Financial Reporting in Hyperinflationary Economics; IAS 19 Employee Benefits and IAS 26 Accounting and Reporting by Retirement Benefit Plans. IAS 29 addresses a problem that Fiji does not presently experience as the inflation rate in Fiji for the past ten years have remained below 10\% 
per annum. Similarly, inappropriate IAS19 and IAS 26 which relate to reporting entity sponsored pension scheme but there is no such employee benefits and retirement Benefit plans in Fiji.

Pathik (2000) in her study on the extent of non-compliance with Fiji Accounting Standards showed that the level of compliance by larger reporting entities was comparable to that in the neighbouring developed countries of Australia and New Zealand. This is attributed to the proactive role of the Fiji Institute of Accountants.

Chand (2005a) notes that in Fiji most of the accounting practices have been placed on the AngloSaxon model. According to Chand (2005a), prior to the formation of the Fiji Institute of Accountants, the MNCs operating in Fiji were, in essence, reporting back to their parent entities and hence were using GAAP of the country where the parent company was domiciled, as Fiji did not have any regulatory framework at that time. This was the practice until the Fiji Institute of Accountants was formed in 1972.

Chand (2005b) analyses the diversity of influences that has led to the adoption of IFRS in Fiji. His study demonstrates that in the case of Fiji, apart from the direct influence of the IASB and the donor agencies, there are many other potent factors encouraging the adoption of the IFRSs. In the case of Fiji, it is observed that the developed countries (especially the UK) imposed the accounting practices, initially, via colonialism, then through the operations of MNCs and professional accounting institutes, despite the nature of the social and economic systems of the developed countries being different from what prevails in Fiji. Also the donor agencies such as the World Bank and other international financial institutions (such as the ADB) have insisted that auditing of many of the projects they finance is carried out by an international firm of accountants and use internationally recognized (i.e. the IFRS or IFRS compliant) accounting standards.

Chand, Patel \& Patel (2010) examine whether there are differences in judgments of professional accountants in Fiji when interpreting and applying selected International Financial Reporting Standards (IFRSs). Their results show that interpretation and application of accounting standards are affected by complexity of the accounting standard and profession accountant's 
familiarity with the standard. The result shows that differences in judgment exist between the Big 4 and non-Big 4 professional accountants when provided with new accounting standards that require complex judgments. The differences in judgments of the Big 4 and non-Big 4 professional accountants were found to be greater if standards are 'new' (unfamiliar) when compared to standards that are 'old' (familiar).

Chand and White (2006) investigate the effect culture has on Fijian accountants judgment and application of IAS/IFRS. The study compares the two ethnic groups in Fiji: the Fijians and IndoFijians. A survey with 135 participants of the membership of Fiji Institute of Accountants was conducted. They utilized Hofstede Value Survey model. Chand and White (2006) found that according to Hofstede's Value Survey Model, the cultural differences found between Fijians and Indo-Fijians is minor. The results also demonstrated that accountants' judgments were not affected by work experiences, level of education, age or gender.

Devi, Kumar and Raju (2012a) explore the need to regulate Chartered accountancy firms in Fiji. Devi et al., (2012a) found that the Commerce Commission and the South Pacific Stock Exchange showed strong support for the establishment of an independent accounting oversight body whereas the Chartered Accountancy firm partners and the Fiji Institute of Accountants did not support this view. The Fiji Institute of Accountants was defensive when questioned about their current effectiveness as regulator. Devi et al., (2012a) conclude that interviewees from non-accounting bodies believed that there is inadequate regulation of the accounting profession and that there was a need for the establishment of an independent oversights body.

Hussain, Chand and Rani (2012) examine the impact of the adoption of IFRS for SMEs on the accounting profession in Fiji. They examine the preparedness, capacity and challenges faced by the big four and non- big four accounting firms in dealing with this adoption. The authors state that medium sized entities would benefit more than small entities. The costs for the adoption of IFRS are ever present but the amount of benefits in emerging economies is still to be realized.

Brown (2009a) examines the internal village reporting that has been taking place in the Nacamaki and Nabuna villages co-operatives in Fiji. Brown (2009a) found that the two villages have adopted two different reporting styles despite their close proximity. The Nabuna village 
has adopted an oral communications style for reporting while the Nacamaki village makes use of traditional -oral and western-narrow handwritten as their reporting style. The Nacamaki village's adoption of western-narrow financial reporting has allowed it to continue under the going concern principle. The author found that the Nabuna village's reliance on an oral reporting style has not aided the Nabuna Co-operative to be a going concern.

Rika, Rotuivaqali, Tuiseke and Finau-Tavite (2008) examine how accounting and accountability concepts are understood by indigenous Fijians. They examine the role accounting and accountability play in the indigenous Fijian provincial council. Rika et al., (2008) found that indigenous Fijians identified several meanings and words regarding 'accountability' but there was no consistent term used. Their paper further explains that it can take up to five years for financial statements to be submitted by provincial councils. Rika et al., (2008) also highlight that there is also a need for Fijian villagers to improve their accounting knowledge so they can utilize the Council's financial statements fully.

Brown (2009b) examines the reporting performance of the Fiji's public sector entities for the period 2001-2005 as evidenced through tabling of annual reports to the Fijian parliament. The investigation takes place in the context of coups that occurred and concerns about Fiji's overall lack of governance. The study finds that throughout the period, few public sectors entities tabled an annual report. When reports are tabled, many are late or do not contain core financial statements. Brown (2009b) indicates that public sector reports are not to be accessible by the Fijian stakeholders due to the fact that they are presented in English but yet there are a lot of Fijian stakeholders that can only read or speak Fijian. While these stakeholders can purchase a copy in Fijian, the sum required falls outside the means of many Fijian stakeholders.

Lodhia and Burritt (2004) examine the public sector accountability failure in context of the National Bank of Fiji. The authors used a case study of National Bank of Fiji and made use of archival data to examine the National Bank of Fiji scandal. The authors found that accounting systems rely on trust in the independent auditing process. However, in emerging economies like Fiji, there are contextual factors that interfere with audit and accounting systems. Lodhia and Burritt (2004) found that irregularities in the National Bank of Fiji existed in the analysis period and the Office of the Auditor General did not fulfil their duties to inform stakeholders and this 
was so due to political patronage and corruption found in the audit and accounting systems in Fiji. The authors concluded that the combination between poor public sector management and corrupt practices shaped the demise of the National Bank of Fiji.

Shailer and Vatuloka's (2000) study examined the preferences of stakeholders in the Fijian public sector reporting process regarding the setting and monitoring of government accounting standards in Fiji. The authors collected data by sending surveys to respondents that they classified as preparers and internal and external users. The authors found that most shareholders believe private financial accounting practices would benefit the Fiji governments accounting process. Shailer and Vatuloka (2000) conclude that all stakeholders in Fijian public sector reporting process are supportive about the introduction of accounting standards for the Fijian public sector. The authors conclude that there was a strong support for the Office of the Auditor General to act as a monitor for departments.

Tickell (2010) examines Fiji's attempt to use accrual accounting as its financial reporting format. His findings suggest that due to the nation's low skilled public service, high labour turnover and a lack of investment in capital equipment, to undertake a move to accrual accounting for this and similar developing nations may warrant a different approach to that used by developed economies. Regular military coups and general instability within the government were detrimental to progress in accrual accounting. Despite the unstable government, the public sector is taking small steps towards accrual accounting. For Fiji, the accrual accounting project is progressing slowly. Questions being posed are, will the benefits of adoption of accrual accounting outweigh costs? As part of the financial Management Reform program, the Fiji government has procured SAP software. SAP is being progressively implemented over a period of time.

White (2005) examines the accounting practices employed by Fiji's superannuation fund of Fiji National Provident Fund. He reports that Fiji National Provident Fund's initial failure to implement financial reporting regulation resulted in over stated return on investment figures. However, Fiji National Provident Fund's later compliance with financial reporting regulation was because of the favourable portrayal of returns the new regulation allowed. White (2005) found that such practices benefited the departing members of Fiji National Provident Fund but 
had a negative impact on newer members. White (2005) concludes that Fiji National Provident Fund reporting practices are opportunistic and that this behavior has had major impacts on stakeholders.

Sharma and Davey (2013a) examine voluntary disclosure by the listed Fijian companies in their annual reports. Sharma and Davey (2013a) collected and analysed the annual reports of 15 companies listed on the South Pacific Stock Exchange from 1999 onwards. Sharma and Davey make use of quantitative content analysis and make use of the counting words as a measurement of the extent and trend of voluntary disclosure by listed companies in Fiji. The authors found that most voluntary disclosure was on shareholders followed by other community concerns and in contrast government regulation and activities had the least coverage. The study found that only 14 of the 15 companies reported voluntary information in each of the years under study. Sharma and Davey (2013a) conclude that the low level of voluntary disclosure overall can be linked to entities in developing economies like Fiji being not pressured into disclosing more information by the stakeholders, reducing their needs to engage in voluntary disclosure to legitimize their activities.

Sharma, Low and Davey (2013b) argued that the trend of voluntary disclosure practices in Fiji have shown a significant improvement. The companies were analysed in light of recent developments in corporate governance by the Capital Market Development Authority implementing their corporate governance principles. This became a major driver of the increase in voluntary disclosure level in the annual reports of the listed companies. The study has shown that corporate governance code issued in 2009 by Capital Market Development Authority has influenced the level of voluntary disclosure.

To sum up, the literature on financial reporting covered areas of convergence of international financial reporting standards, public sector reporting, indigenous accounting practices and voluntary disclosure. The accounting system in Fiji has been strongly influenced by the British and more recently by international arrangements and practices. However, the International Financial Reporting System needs to take into consideration the interplay of local and cultural forces within Fiji. The indigenous financial reporting saw oral reporting versus western reporting. The businesses with oral reporting were not so sustainable when compared to the 
western style of reporting by businesses. There was also call for financial reports to be available in indigenous Fijian language for a better understanding by stakeholders. Regular political instability seemed to constrain the adoption of accrual accounting in the public sector. There has been some improvement in voluntary disclosure reporting which is mainly attributed to the 2009 corporate governance code issued by the Capital Market Development Authority. More research is needed in the indigenous business reporting in Fiji as well as research on voluntary disclosure. The use of various methods such as survey or interviews can shed new insights into such research which seemed to be lacking at the moment. We will now review the literature on corporate governance.

\subsection{Corporate Governance}

This section reports about three related papers on corporate governance practices in Fiji. The topic of corporate governance on Fiji is under represented in the literature accounting for only three papers $(7.5 \%)$ of total papers reviewed. Much more needs to be done on this important area of research which can take a variety of research approaches. We review the three papers.

Mala and White (2009) use a case study approach to examine why companies in Fiji list on a stock exchange. They found that the influences that motivated companies in Fiji to list entailed enhancing their image and reputation, increasing the firm's value and introducing better financial and managerial practices. Importantly, the accessing of new sources of finance has not been a detriment of a company's listing decision. Mala and White (2009) find that listed companies in Fiji view IPO as a strategic reputation enhancing move and as a means of establishing and improving the market values of the company, rather than as a financing decision. Concerns expressed by potential companies not to list included the issue of corporate control. For those 'potential to list companies', fear of loss of control and fear of disclosing the financial

performance to competitors are pertinent factors in making the decision to list or not to list. Mala and White (2009) conclude that Fiji's investing class has yet to perceive the benefit which can be accrued by holding securities and in particular equities as compared to other forms of investment. 
Reddy and Sharma (2011) focuses on the nature and effectiveness of principle-based corporate governance initiatives in encouraging better governance in companies listed on the South Pacific Stock Exchange. The authors found that the listed companies had created value for shareholders as measured by Tobin's Q. Their interview evidence with CEO of the South Pacific Stock Exchange revealed that the companies are upfront when it comes to information that would reflect positive information, but are often reluctant to report negative information. Reddy and Sharma (2011) found that block holding is relatively high among these listed companies and that insiders own a large portion of these companies which renders the welfare of minor shareholders at risk. The authors conclude that listed companies have adopted corporate governance practices as a way to preserve legitimacy.

Reddy and Sharma (2014) using more recent data investigate the nature and extent of compliance to the principle-based corporate governance initiatives by the listed companies in the South Pacific Stock Exchange in Fiji. The findings indicate that listed companies have adopted the Capital Market Development Authority's recommendations by establishing subcommittees for audit and remuneration, having non-executive independent directors on the board and separate chair and CEO positions in order to gain legitimacy from stakeholders. Results support the view that the Capital Market Development Authority recommendation of board sub-committees (audit and remuneration) has had positive influence on company performance measured by Tobin's Q. The findings of this study gave support to the principle-based corporate governance practices adopted in Fiji to gain legitimacy. The evidence from Fiji's stock exchange, South Pacific Stock Exchange, also suggests that listed companies have complied with the corporate governance code.

To sum up, investors in Fiji seemed to be not favouring equity form of investment and instead prefer to keep their money in bank accounts. The market seems to underdeveloped in this sense. Block shareholding is common in Fiji and so protection of minority shareholders' interest is imperative. However, the listed company has adhered to corporate governance code issued by Capital Markets Development Authority. The studies on corporate governance practices in Fiji are limited and more studies need to be undertaken in this area. There is a need for employing other research approaches such as surveys, interviews and archival data research on corporate 
governance practices not only on private sector but also in in the public sector and the small and medium business enterprises. The next section examines the remaining studies.

\subsection{Remaining Studies}

The findings of three papers which could not be related to each of the identified themes are briefly discussed here. Davie (2000b) critically analyses the involvement of accounting in imperial expansion in the South Pacific during the mid-nineteenth to mid-twentieth Century. There was collaboration between chiefs and British in the British expansion into Fiji. However, accounting was a problem for the indigenous chiefs as the root of trouble was not technical but emanates from Fijian social attitudes which were at variance with European standards of administration. The study shows how accounting was used as a mechanism through which an imposed collaborative system of domination and exploitation through alliance with indigenous chiefs was achieved during annexation. Davie (2000b) demonstrates the manner in which the British used indigenous chiefly hegemonic structure to exploit both human and other natural resources for their empire building.

Devi, Kumar and Raju (2012b) examine the viability of the partnering with practice approach to teaching accounting in school of Accountancy and Finance at the University of the South Pacific. Devi et al., (2012b) examine whether there is an expectation gap in the accounting curriculum and whether a partnering with practice (PWP) approach could overcome this. Devi et al., (2012b) found that both academics and CA partners perceived benefits and limitations of adopting a PWP approach. The major benefit was the improvement in the quality of accounting education and graduates. The major limitation was the workload CA partners faced. Devi et al., (2012b) conclude that both academics and CA partners would be willing to collaborate in the delivery of accounting courses vis a PWP approach.

Lodhia (1999) examines the environmental accounting practice of the only public company, the Fiji Sugar Corporation that discloses environmental information in its annual report and the motives for disclosure. Lodhia (1999) found that Fiji Sugar Corporation undertakes environmental accounting as a way to legitimize its business operations rather than accountability awareness to stakeholders. The study found that there were no formal 
environmental plans or policies in place at the Fiji Sugar Corporation. Lodhia (1999) concludes that accountants have limited involvement in organisations environmental management strategies. Fiji Sugar Corporation's environmental practices can be concluded as being patchy and inadequate. The Fiji Sugar Corporation's environmental reporting is only a way of the company legitimising its sensitive aspects of the manufacturing operations.

\section{Conclusions and research agenda}

The main goal of this review was to take stock of the body of knowledge of Fiji's accounting literature. The review reveals that much more research needs to be done on the identified themes using a variety of research approaches. While there is adequate literature on new public management and financial reporting/accountability, there is a lack of research in the areas of corporate governance, indigenous accounting, accounting education, sustainability accounting and more importantly accounting history studies.

Another observation from the review is that the theoretical contributions emanating from the Fijian accounting literature is relatively little. Almost half of the reviewed papers had no theoretical contributions to make. Wherever, theoretical contributions were covered, this mainly engaged with institutional theory or social theory. There is a need for more studies in Fijian context to engage with critical theorizing or even with other theories.

There is also a need to get an in-depth insight into management accounting practices in Fiji. Qualitative research seems to be relatively more important than quantitative research in this respect as it is primarily directed to finding a deeper understanding of accounting practices of a single or a fewer organisations by giving emphasis to the particularities of these organisations including their context.

Given the influence of international donor agencies and their agenda for advocating rational decision making in Fiji, there remains a need for critical research by academics about the implicit value of this agenda and its impact on accounting practices. Which forms of accounting is appropriate and under what conditions could be useful interesting research questions for future research. In general, critical research about the influence of donor agencies in management accounting practices may benefit from social and critical theories. 
We conclude that more future work is needed in the area of accounting history which includes topics such as accounting and the state, performance auditing, indigenous accounting, financial reporting, SMEs, and accountability in general. Data for such research can be sourced from the National Archives of Fiji in Suva, University of the South Pacific's library's Pacific collection section and professional bodies such as Fiji Institute of Accountants and its library. There are some vital web sites which could also be utilized to source archival data which entails Fiji Institute of Accountants, South Pacific Stock Exchange, Fiji government websites amongst others.

We believe that the domain of accounting research in Fiji will be an enlightening as well as a challenging one given the political instability she has faced in the past. There are areas that are relatively unexplored. Broadening our research horizons will enable us to unfold some new and interesting insights into Fiji's accounting literature. We, as accounting researchers, need to contribute to this country specific accounting literature. 
Appendix A Categorization of the papers in this review according to accounting topics, themes, methods of data collection and main findings.

\begin{tabular}{|c|c|c|c|c|c|}
\hline Author & $\begin{array}{l}\text { Journal } \\
\text { (year) }\end{array}$ & Topic & Theories & Methods & Main Findings \\
\hline $\begin{array}{l}\text { Alam, } \\
\text { Lawrence,Nandan }\end{array}$ & $\begin{array}{l}\text { CPA } \\
2004\end{array}$ & $\begin{array}{l}\text { New public } \\
\text { management }\end{array}$ & $\begin{array}{l}\text { Giddens } \\
\text { Structuration } \\
\text { theory }\end{array}$ & Case study & $\begin{array}{l}\text { The establishment of profit centres at the branch level of } \\
\text { the Fiji Development Bank and insistence on profit-driven, } \\
\text { commercialized loan and repayment policies contrast with } \\
\text { the communal culture of its indigenous people. }\end{array}$ \\
\hline Brown & $\begin{array}{l}\text { PAR } \\
2009\end{array}$ & Financial reporting & No theory & $\begin{array}{l}\text { Fieldwork- } \\
\text { case studies }\end{array}$ & $\begin{array}{l}\text { The } 2 \text { villages of Nacamaki and Nabuna have adopted two } \\
\text { different financial reporting styles despite their close } \\
\text { proximity. Nabuna village had oral communication style } \\
\text { for reporting while Nacamaki village made use of } \\
\text { traditional-oral and western narrow handwritten as their } \\
\text { reporting style. The Nacamaki village adoption of western } \\
\text { narrow financial reporting has allowed it to continue under } \\
\text { the going concern while Nabuna's reliance on oral } \\
\text { reporting has not aided its co-operative to be a going } \\
\text { concern. }\end{array}$ \\
\hline Brown & $\begin{array}{l}\text { FRRG } \\
2006\end{array}$ & $\begin{array}{l}\text { Public } \quad \text { sector } \\
\text { accountability }\end{array}$ & $\begin{array}{l}\text { Theory } \\
\text { aesthetics } \\
\text { ambiguity }\end{array}$ & $\begin{array}{l}\text { Archival } \\
\text { data/ Policy } \\
\text { Studies }\end{array}$ & $\begin{array}{l}\text { Throughout 2001-2005 period of study, few public sector } \\
\text { entities table an annual report. When reports are tabled, } \\
\text { many are late or do not contain core financial statements. } \\
\text { The reports are not accessible by Fijian stakeholders as } \\
\text { they are presented in English and many can only read or } \\
\text { speak Fijian. }\end{array}$ \\
\hline Chand & $\begin{array}{l}\text { CPA } \\
2005 a\end{array}$ & Financial Reporting & No theory & $\begin{array}{l}\text { Archival } \\
\text { data }\end{array}$ & $\begin{array}{l}\text { In Fiji, most of the accounting practices have been placed } \\
\text { in the Anglo-Saxon model. Prior to the formation of the } \\
\text { Fiji Institute of Accountants, the multinational corporations } \\
\text { (MNCs) operating in Fiji were reporting back to their } \\
\text { parent entities and hence were utilizing GAAP of the } \\
\text { country where the parent entity was domiciled as Fiji did } \\
\text { not have any regulatory framework at that time. }\end{array}$ \\
\hline Chand & $\begin{array}{l}\text { JPS } \\
2005 b\end{array}$ & Financial Reporting & No theory & $\begin{array}{l}\text { Literature } \\
\text { review/ } \\
\text { archival data }\end{array}$ & $\begin{array}{l}\text { Apart from the direct influence of IASB and donor } \\
\text { agencies in Fiji, there are many other potent factors } \\
\text { encouraging the adoption of the IFRSs. This entails MNCs } \\
\text { and professional accounting institutes. }\end{array}$ \\
\hline Chand & $\begin{array}{l}\text { MA } \\
2002 \\
\end{array}$ & $\begin{array}{l}\text { Financial Reporting/ } \\
\text { Accountability }\end{array}$ & No theory & $\begin{array}{l}\text { Archival } \\
\text { data. }\end{array}$ & $\begin{array}{l}\text { The development of Fiji Island's accounting profession } \\
\text { dates back to the } 1940 \mathrm{~s} \text { when the Governor accepted the }\end{array}$ \\
\hline
\end{tabular}




\begin{tabular}{|c|c|c|c|c|c|}
\hline & & & & & $\begin{array}{l}\text { proposal to register tax agents. Registered accountant } \\
\text { numbers grew from just } 13 \text { in } 1963 \text { to only } 40 \text { by } 1970 \text {. } \\
\text { The government passed Fiji Institute of Accountants Act } \\
\text { 1971. The act provided for the Fiji Institute of } \\
\text { Accountants establishment. }\end{array}$ \\
\hline Chand \& Patel & $\begin{array}{l}\text { AA } \\
2008\end{array}$ & Financial Reporting & No theory & $\begin{array}{l}\text { Archival } \\
\text { data. }\end{array}$ & $\begin{array}{l}\text { The Companies Act (1983) and the pronouncement of the } \\
\text { Fiji Institute of Accountants provide the legal and } \\
\text { regulatory framework for financial reporting in Fiji. }\end{array}$ \\
\hline Chand, Patel, Patel & $\begin{array}{l}\text { AA } \\
2010\end{array}$ & Financial Reporting & Hypotheses testing & $\begin{array}{l}\text { Experimental } \\
\text { research }\end{array}$ & $\begin{array}{l}\text { The interpretation and application of accounting standards } \\
\text { are affected by complexity of the accounting standard and } \\
\text { professional accountant's familiarity with the standard. } \\
\text { The results show that differences in judgment exist } \\
\text { between the Big } 4 \text { and non-Big } 4 \text { professional accountants } \\
\text { when provided with new accounting standards that require } \\
\text { complex judgments. }\end{array}$ \\
\hline Chand \& White & $\begin{array}{l}\text { CPA } \\
2007\end{array}$ & $\begin{array}{ll}\text { Financial } & \text { Reporting/ } \\
\text { accountability } & \end{array}$ & No theory & $\begin{array}{l}\text { Literature } \\
\text { review }\end{array}$ & $\begin{array}{l}\text { Fiji willingly accepted IFRS's. This was due to private } \\
\text { interests- multinational enterprises and large international } \\
\text { firms can shape transfer of economic resources in their } \\
\text { favour. The Fiji Institute of Accountants adopted the IFRS } \\
\text { in their quest to satisfy the needs of all stakeholders in Fiji. }\end{array}$ \\
\hline Chand \& White & $\begin{array}{l}\text { AAR } \\
2006\end{array}$ & Financial Reporting & No theory & $\begin{array}{l}\text { Survey }- \\
\text { Hofstede } \\
(1994) \text { value } \\
\text { survey } \\
\text { model. }\end{array}$ & $\begin{array}{l}\text { Using Hofstede value survey model, it was found that the } \\
\text { cultural differences found between Fijian and Indians is } \\
\text { minor in relation to accountants' judgment and application } \\
\text { of IAS/IFRS. The accountants' judgments in the } \\
\text { application of IAS/IFRS were not affected by work } \\
\text { experience, level of formal education, age or gender. }\end{array}$ \\
\hline Davie & $\begin{array}{l}\text { RAET } \\
2004\end{array}$ & New public management & Critical theory & Case study & $\begin{array}{l}\text { That the use of accounting language in constructing the } \\
\text { reality of forestry activities is not compatible with the } \\
\text { tradition of the community in which it was imposed. } \\
\text { Communal expectations and obligations overrode capitalist } \\
\text { technology in her field study. }\end{array}$ \\
\hline Davie & $\begin{array}{l}\text { CPA } \\
2000 \mathrm{a}\end{array}$ & New public management & $\begin{array}{l}\text { Theoretical notion } \\
\text { of 'ambiguity'- } \\
\text { critical theory }\end{array}$ & $\begin{array}{l}\text { Case study- } \\
\text { ethnography. }\end{array}$ & $\begin{array}{l}\text { In the pine industry in Fiji, there were conceptual } \\
\text { incomprehensibility of accounting by land owners such as } \\
\text { they could not understand the notion of profit, discounting, } \\
\text { depreciation as this was alien to the Fijian culture. }\end{array}$ \\
\hline Davie & $\begin{array}{l}\text { AAAJ } \\
2000 b\end{array}$ & $\begin{array}{l}\text { Accounting } \\
\text { colonialism }\end{array}$ & Critical theory. & $\begin{array}{l}\text { Archival } \\
\text { records. }\end{array}$ & $\begin{array}{l}\text { Accounting was involved in imperial expansion in the } \\
\text { South Pacific during the mid-nineteenth century. There was } \\
\text { a collaboration between chiefs and the British in the British }\end{array}$ \\
\hline
\end{tabular}




\begin{tabular}{|c|c|c|c|c|c|}
\hline & & & & & $\begin{array}{l}\text { expansion into Fiji. However, accounting was a problem } \\
\text { for the indigenous chiefs as the root of the trouble was not } \\
\text { technical but emanates from Fijian social attitudes which } \\
\text { were at variance with European standards of } \\
\text { administration. The research demonstrated the manner in } \\
\text { which the British used indigenous chiefly hegemonic } \\
\text { structure to exploit both human and other natural resources } \\
\text { for their empire building. }\end{array}$ \\
\hline $\begin{array}{ll}\text { Devi, Kumar \& } \\
\text { Raju }\end{array}$ & $\begin{array}{l}\text { GJBR } \\
2012 a\end{array}$ & $\begin{array}{lr}\text { Accountability } & \& \\
\text { regulation/ } & \text { Financial } \\
\text { reporting } & \end{array}$ & No theory & $\begin{array}{l}\text { Interviews/ } \\
\text { Survey }\end{array}$ & $\begin{array}{l}\text { The Commerce Commission and South Pacific Stock } \\
\text { Exchange showed strong support for the establishment of } \\
\text { an independent accounting oversight body while Chartered } \\
\text { Accountant firm partners and the Fiji Institute of } \\
\text { Accountants did not support this and found the Fiji } \\
\text { Institute of Accountants regulation as adequate. The Fiji } \\
\text { Institute of Accountants was defensive when questioned } \\
\text { about their current effectiveness on accounting regulation. }\end{array}$ \\
\hline $\begin{array}{l}\text { Devi, Kumar \& } \\
\text { Raju }\end{array}$ & $\begin{array}{l}\text { BEA } \\
2012 b\end{array}$ & Accounting education & No theory & Survey & $\begin{array}{l}\text { Both academics and Chartered accountants partners } \\
\text { perceived benefits and limitations of adopting Partnering } \\
\text { with Practice (PWP) approach. The major benefits were the } \\
\text { improvement in the quality of accounting education and } \\
\text { graduates. The major limitation was the workload that } \\
\text { Chartered accountant partners faced. }\end{array}$ \\
\hline $\begin{array}{l}\text { Hussain, Chand \& } \\
\text { Rani }\end{array}$ & $\begin{array}{l}\text { AT } \\
2012\end{array}$ & Financial Reporting & No theory & $\begin{array}{l}\text { Interviews/ } \\
\text { Survey }\end{array}$ & $\begin{array}{l}\text { The Big } 4 \text { auditing firms have an advantage over non-big } \\
\text { four firms as Big } 4 \text { firms have exposure to IFRS. The } \\
\text { practitioners interviewed were concerned that the adoption } \\
\text { costs for SMEs would outweigh the benefits. The costs for } \\
\text { the adoption of IFRS by SMEs are ever present but the } \\
\text { amount of benefits in emerging economies are still to be } \\
\text { realized. }\end{array}$ \\
\hline Irvine \& Deo & $\begin{array}{l}\text { AAAJ } \\
2006\end{array}$ & $\begin{array}{l}\text { New public } \\
\text { management/accountability }\end{array}$ & $\begin{array}{l}\text { Weber's theory of } \\
\text { rationality and } \\
\text { Marxist theory }\end{array}$ & Case study & $\begin{array}{l}\text { The case on Fiji Development Bank demonstrates how a } \\
\text { different theoretical lens has on the selection and } \\
\text { interpretation of events. Fiji Development Bank has been } \\
\text { faced with an enormous impossible task, that of reconciling } \\
\text { the profit motive with the cooperative culture of Fijians. } \\
\text { The authors' interpretation through Weber's theory of } \\
\text { rationality views Fiji Development Bank's goal as } \\
\text { achievable. The role of accounting has been enabling } \\
\text { unlike the view from Marxist theory which views role of } \\
\text { accounting as imposed and negative. }\end{array}$ \\
\hline
\end{tabular}




\begin{tabular}{|c|c|c|c|c|c|}
\hline Juchau & $\begin{array}{l}\text { AA } \\
1978\end{array}$ & Financial reporting & No theory & $\begin{array}{l}\text { Archival } \\
\text { data }\end{array}$ & $\begin{array}{l}\text { Fiji's accounting system were historically influenced by } \\
\text { the colonial power and further reinforced by the work of } \\
\text { expatriate professional accountants and the establishment } \\
\text { of multinational accounting firms. }\end{array}$ \\
\hline Kapadia & $\begin{array}{l}\text { FA } \\
1980\end{array}$ & $\begin{array}{ll}\text { Financial } & \text { Reporting/ } \\
\text { Accountability } & \end{array}$ & No theory & $\begin{array}{l}\text { Archival } \\
\text { data }\end{array}$ & $\begin{array}{l}\text { The expatriate professional accountants were responsible } \\
\text { for establishing the professional institutes and the ethos of } \\
\text { the accounting profession in Fiji. The Fiji Institute of } \\
\text { Accountants through its Accounting and Auditing } \\
\text { committee promulgates accounting standards which serves } \\
\text { as the basis for preparing the financial statements. }\end{array}$ \\
\hline Kukeraja & $\begin{array}{l}\text { FA } \\
1997\end{array}$ & Financial Reporting & No theory & $\begin{array}{l}\text { Archival } \\
\text { data }\end{array}$ & $\begin{array}{l}\text { The membership of the Fiji Institute of Accountants } \\
\text { comprises both Fiji national and expatriates who generally } \\
\text { receive their accounting education in Commonwealth } \\
\text { countries. The accounting practices in Fiji are aligned with } \\
\text { the Anglo-Saxon accounting model. }\end{array}$ \\
\hline $\begin{array}{l}\text { Lawrence, Sharma, } \\
\text { Nandan. }\end{array}$ & $\begin{array}{l}\text { IJCA } \\
2009\end{array}$ & New public management & Institutional theory & Case study & $\begin{array}{l}\text { Soon after the introduction of public sector reform, the } \\
\text { management at Housing Authority of Fiji used power } \\
\text { relation to implement innovative accounting and control } \\
\text { system. Those employed from the private sector along } \\
\text { with the consultants were carriers of change. The changes } \\
\text { in the organisation's system shaped the organization to lose } \\
\text { sight of its original purpose which was to house under } \\
\text { privileged people who were locked out of the housing } \\
\text { market. }\end{array}$ \\
\hline Lodhia & $\begin{array}{l}\text { JPS } \\
1999\end{array}$ & Sustainability accounting & Legitimacy theory & Case study & $\begin{array}{l}\text { The case study, Fiji Sugar corporation, undertakes } \\
\text { environmental accounting as a way to legitimise its } \\
\text { business operations rather than accountability awareness to } \\
\text { stakeholders. There were no formal environmental plans } \\
\text { or policies in place at Fiji Sugar corporation. Accountants } \\
\text { had limited involvement in organisations environmental } \\
\text { management strategies. }\end{array}$ \\
\hline Lodhia \& Burritt & $\begin{array}{l}\text { IJPSM } \\
2004\end{array}$ & $\begin{array}{l}\text { Public sector } \\
\text { accountability }\end{array}$ & No theory & Case study & $\begin{array}{l}\text { The collapse of the National Bank of Fiji was due to the } \\
\text { contextual factors (political patronage) that interfere with } \\
\text { audit and accounting systems. The irregularities in the } \\
\text { National Bank of Fiji existed in the analysed period and the } \\
\text { Office of the Auditor General did not fulfil their duties to } \\
\text { inform stakeholders and this was possible due to corruption } \\
\text { found in the audit and accounting systems in Fiji. }\end{array}$ \\
\hline Mala \& White & $\begin{array}{l}\text { AAR } \\
2009\end{array}$ & Corporate governance & No theory & Case study & $\begin{array}{l}\text { The influences that motivated companies in Fiji to list on } \\
\text { the stock exchange entailed enhancing their image and }\end{array}$ \\
\hline
\end{tabular}




\begin{tabular}{|c|c|c|c|c|c|}
\hline & & & & & $\begin{array}{l}\text { reputation, increasing the firm's value and introducing } \\
\text { better financial and managerial practices. For those } \\
\text { 'potential to list companies', fear of loss of control and fear } \\
\text { of disclosing the financial information to competitors are } \\
\text { pertinent factors in making the decision to list or not to list. }\end{array}$ \\
\hline Nandan \& Alam & $\begin{array}{l}\text { RAET } \\
2004\end{array}$ & New public management & $\begin{array}{l}\text { Structuration } \\
\text { theory }\end{array}$ & Case study & $\begin{array}{l}\text { The introduction of a new profit-based significance } \\
\text { structure in the 1990s at the Fiji Development Bank } \\
\text { replaced the old development based signification structure. } \\
\text { The profit-based structure provided the dominant language } \\
\text { and meaning for actions and interactions within the Fiji } \\
\text { Development Bank. }\end{array}$ \\
\hline Nath \& Sharma & $\begin{array}{l}\text { AAR } \\
2014\end{array}$ & $\begin{array}{l}\text { Performance management } \\
\text { system/ New public } \\
\text { management }\end{array}$ & $\begin{array}{l}\text { Diffusion of } \\
\text { innovation theory }\end{array}$ & Case study & $\begin{array}{l}\text { With growing pressure for commercialization from donor } \\
\text { agencies, the accounting and managerial practices seem to } \\
\text { contradict the organisation's original purpose to provide } \\
\text { housing needs for the poor. There was a disconnect } \\
\text { between the performance management system and its } \\
\text { actual use at the public housing organisation in Fiji. }\end{array}$ \\
\hline Pathik & $\begin{array}{l}\text { MA } \\
2000\end{array}$ & Financial Reporting & No theory & $\begin{array}{l}\text { Archival } \\
\text { data/ annual } \\
\text { reports of } \\
\text { publicly } \\
\text { listed } \\
\text { companies }\end{array}$ & $\begin{array}{l}\text { The level of compliance with Fiji Accounting Standard by } \\
\text { large reporting entities was comparable to that in the } \\
\text { neighboring developed countries of Australia and New } \\
\text { Zealand. This is partly attributed to the proactive role of } \\
\text { the Fiji Institute of Accountants. }\end{array}$ \\
\hline Reddy \& Sharma & $\begin{array}{l}\text { FS } \\
2011\end{array}$ & Corporate governance & Institutional theory & $\begin{array}{l}\text { Archival } \\
\text { data and } \\
\text { interview }\end{array}$ & $\begin{array}{l}\text { The listed companies create value for shareholders as the } \\
\text { market value of share were greater than their book value. } \\
\text { Companies were upfront when it comes to information that } \\
\text { would reflect positively on the company but would shy } \\
\text { away from negative news. Block holding is relatively high } \\
\text { among these companies which put the welfare of minor } \\
\text { stakeholders at risk. The listed companies have adopted } \\
\text { corporate governance practices as a way to preserve } \\
\text { legitimacy. }\end{array}$ \\
\hline Reddy \& Sharma & $\begin{array}{l}\text { JAOC } \\
2014\end{array}$ & Corporate governance & Institutional theory & $\begin{array}{l}\text { Archival } \\
\text { data and } \\
\text { regression } \\
\text { analysis }\end{array}$ & $\begin{array}{l}\text { Listed companies have adopted the Capital Market } \\
\text { Development Authority's recommendations by establishing } \\
\text { subcommittees for auditing and remuneration, having non- } \\
\text { executive independent directors on the board and separate } \\
\text { chair and CEO positions in order to gain legitimacy from } \\
\text { stakeholders. Results support the view that the Capital } \\
\text { Market Development Authority recommendations of board }\end{array}$ \\
\hline
\end{tabular}




\begin{tabular}{|c|c|c|c|c|c|}
\hline & & & & & $\begin{array}{l}\text { sub-committees (audit and remuneration) have had positive } \\
\text { influence on company performance measured by Tobin's } \\
\text { Q. The evidence from Fiji's Stock Exchange also suggests } \\
\text { that listed companies have complied with the corporate } \\
\text { governance code. }\end{array}$ \\
\hline $\begin{array}{l}\text { Rika, Rotuivaqali, } \\
\text { Tuiseke \& Finau- } \\
\text { Tavite }\end{array}$ & $\begin{array}{l}\text { AABF } \\
2008\end{array}$ & $\begin{array}{l}\text { Financial Reporting and } \\
\text { accountability }\end{array}$ & No theory & Case study & $\begin{array}{l}\text { While indigenous provincial councils uphold their } \\
\text { accounting responsibilities, it is an untimely process } \\
\text { despite the regulation. It can take up to five years for } \\
\text { financial statements to be submitted. The term } \\
\text { 'accountability' was not clear to the indigenous Fijians } \\
\text { who identified different meanings for that. There is a } \\
\text { greater need for accounting literacy amongst the villagers.. }\end{array}$ \\
\hline Shailer \& Vatuloka & $\begin{array}{l}\text { ARA } \\
2000\end{array}$ & $\begin{array}{l}\text { Public sector } \\
\text { accountability/ Financial } \\
\text { Reporting }\end{array}$ & No theory & $\begin{array}{l}\text { Survey } \\
\text { method }\end{array}$ & $\begin{array}{l}\text { Most stakeholders believed that private financial } \\
\text { accounting practices would benefit the Fijian government } \\
\text { accounting process. All stakeholders in Fijian public } \\
\text { sector reporting process were supportive about the } \\
\text { introduction of accounting standards for the Fijian public } \\
\text { sector. }\end{array}$ \\
\hline Sharma \& Davey & $\begin{array}{l}\text { IJEA } \\
2013\end{array}$ & $\begin{array}{l}\text { Voluntary disclosure/ } \\
\text { Financial reporting }\end{array}$ & Legitimacy theory & $\begin{array}{l}\text { Archival } \\
\text { data/ content } \\
\text { analysis of } \\
\text { annual report }\end{array}$ & $\begin{array}{l}\text { Most voluntary disclosure by listed companies was on } \\
\text { shareholders followed by other community concerns and in } \\
\text { contrast government regulation and activities had the least } \\
\text { disclosure. The low level of voluntary disclosure overall } \\
\text { can be linked to the fact that entities in developing } \\
\text { countries like Fiji are not pressured into disclosing more } \\
\text { information by the stakeholders. This reduces the } \\
\text { companies need to engage in voluntary disclosure to } \\
\text { legitimise their activities. }\end{array}$ \\
\hline Sharma \& Hoque & $\begin{array}{l}\text { IJPSM } \\
2002\end{array}$ & New public management & Institutional theory & Case study & $\begin{array}{l}\text { The workers at Housing Authority were reluctant to } \\
\text { implement total quality management practices but through } \\
\text { training this problem was mitigated. The implementation of } \\
\text { total quality management was successful because the } \\
\text { initiative was supported by top management and this } \\
\text { acceptance filtered down through the organization. After } \\
\text { the implementation of total quality management, loans at } \\
\text { Housing Authority were approved much quicker and the } \\
\text { employees adopted a greater customer focus. }\end{array}$ \\
\hline $\begin{array}{l}\text { Sharma } \quad \& \\
\text { Lawrence }\end{array}$ & $\begin{array}{l}\text { JAOC } \\
2005\end{array}$ & New public management & $\begin{array}{l}\text { Institutional theory } \\
\text { and technical- } \\
\text { rational } \\
\text { perspective }\end{array}$ & Case study & $\begin{array}{l}\text { The state rental organization of Public Rental Board } \\
\text { implemented private sector business technologies such as } \\
\text { economic rents, sale of state houses and performance } \\
\text { measurement in the form of the balanced scorecard. The }\end{array}$ \\
\hline
\end{tabular}




\begin{tabular}{|c|c|c|c|c|c|}
\hline & & & & & $\begin{array}{l}\text { varied private sector measures obscured the original } \\
\text { mission of housing the poor. }\end{array}$ \\
\hline $\begin{array}{l}\text { Sharma } \\
\text { Lawrence }\end{array}$ & $\begin{array}{l}\text { AAR } \\
2008\end{array}$ & New public management & Institutional theory & Case study & $\begin{array}{l}\text { The changes in business routines at Fiji Post and } \\
\text { Telecommunication were slow and not widely accepted. It } \\
\text { was communitarian values and tribal obligations in the } \\
\text { form of managements' personal relationships that triggered } \\
\text { a resistance to change to business routines. The top } \\
\text { management had to overcome the resistance to change } \\
\text { which took a while before employees could assimilate new } \\
\text { business routines amidst some signs of resistance still } \\
\text { being present. }\end{array}$ \\
\hline $\begin{array}{l}\text { Sharma } \quad \& \\
\text { Lawrence }\end{array}$ & $\begin{array}{l}\text { PAR } \\
2009\end{array}$ & New public management & $\begin{array}{lr}\text { Laughlin's } & (1991) \\
\text { first order } & \text { and } \\
\text { second } & \text { order } \\
\text { change } & \end{array}$ & Case study & $\begin{array}{l}\text { Both Housing Authority and Telecom Fiji underwent } \\
\text { directional changes to control and accounting systems after } \\
\text { the public sector reforms of the government. The Housing } \\
\text { Authority change agents focused on making profit which } \\
\text { overrode the organsations function to look after the welfare } \\
\text { of poor Fijians who were locked out of the housing market. } \\
\text { There was greater resistance to change at Telecom Fiji } \\
\text { when compared to Housing Authority. Fijian political and } \\
\text { cultural forces contributed to the resistance to change. }\end{array}$ \\
\hline $\begin{array}{l}\text { Sharma, Lawrence } \\
\& \text { Fowler }\end{array}$ & $\begin{array}{l}\text { AH } \\
2012\end{array}$ & New public management & $\begin{array}{l}\text { Critical theory of } \\
\text { governmentality }\end{array}$ & Case study & $\begin{array}{l}\text { Investigates tension between the implementation of new } \\
\text { public management and associated accounting technologies } \\
\text { in the Fiji telecommunication sector and the indigenous } \\
\text { Fijian culture and political structure. In the Fiji telecom } \\
\text { company, the cultural conflicts and political influences led } \\
\text { to the new public management process being resisted and } \\
\text { modified to reduce the tension between economic and } \\
\text { social relations. }\end{array}$ \\
\hline $\begin{array}{l}\text { Sharma, Lawrence } \\
\text { \& Lowe }\end{array}$ & $\begin{array}{l}\text { MAR } \\
2010\end{array}$ & New public management & Institutional theory & Case study & $\begin{array}{l}\text { The motive behind introduction of total quality } \\
\text { management practices at Telecom Fiji was to gain } \\
\text { legitimacy from the stakeholders. The normative } \\
\text { institutional pressure such as the consultants was } \\
\text { instrumental in bringing total quality management practices } \\
\text { into Telecom Fiji limited. The Telecom Fiji Limited CEO } \\
\text { and management team were instrumental in the adoption of } \\
\text { total quality management practices as they were identified } \\
\text { as institutional entrepreneurs and being able to overcome } \\
\text { embedded agency to adopt TQM practices. }\end{array}$ \\
\hline Sharma, Low \& & IJEA & Voluntary disclosure & Legitimacy theory & Archival & It can be seen from the Fiji perspective that the mandatory \\
\hline
\end{tabular}




\begin{tabular}{|c|c|c|c|c|c|}
\hline Davey & 2013 & & & data & $\begin{array}{l}\text { requirements tend to have a financial focus. All companies } \\
\text { showed some degree of voluntary disclosure, and on } \\
\text { average this demonstrates an increasing trend. The } \\
\text { companies were analysed in light of recent developments } \\
\text { in corporate governance by the Capital Markets } \\
\text { Development Authority implementing their corporate } \\
\text { governance principles. This became a major driver of the } \\
\text { increase in levels of the voluntary disclosures in the annual } \\
\text { reports of the listed companies. }\end{array}$ \\
\hline $\begin{array}{l}\text { Tickell } \\
2010\end{array}$ & $\begin{array}{l}\text { IBER } \\
2010\end{array}$ & Financial reporting & No theory & $\begin{array}{l}\text { Case } \\
\text { of } \\
\text { sectudies } \\
\text { sublic }\end{array}$ & $\begin{array}{l}\text { Due to Fiji's low-skilled public service, high labour } \\
\text { turnover, and lack of investment in capital equipment, to } \\
\text { undertake a move to accrual accounting for this and similar } \\
\text { developing nations may warrant a different approach to } \\
\text { that used by developed economies. Despite political } \\
\text { instability, the public sector is taking small steps towards } \\
\text { accrual accounting. For Fiji, the accrual accounting project } \\
\text { is progressing slowly. }\end{array}$ \\
\hline White & $\begin{array}{l}\text { FS } \\
2005\end{array}$ & Financial reporting & No theory & Case study & $\begin{array}{l}\text { Initially, Fiji National Provident Fund which is a } \\
\text { superannuation fund in Fiji failed to follow the financial } \\
\text { reporting regulation which resulted in overstated return on } \\
\text { investment. Fiji National Provident Fund's later } \\
\text { compliance with financial reporting was because of the } \\
\text { favourable portrayal of returns the new regulation allowed. } \\
\text { The practices of the Fund benefitted members who would } \\
\text { be leaving the scheme soon but will be detrimental to those } \\
\text { who will be in the scheme longer. }\end{array}$ \\
\hline
\end{tabular}

Abbreviated journals in the appendix:

$\mathrm{AA}=$ Advances in Accounting; AAR= Australian Accounting Review; ARA= Asian Review of Accounting; AAAJ= Accounting, Auditing and Accountability Journal; AT= Accounting \& Taxation; AABF= Australasian Accounting Business \& Finance Journal; AH= Accounting History; BEA = Business Education \& Accreditation; $\mathrm{CPA}=$ Critical Perspectives on Accounting; FA= Fiji Accountant; FRRG= Financial Reporting Regulation \& Governance; FS= Fijian Studies; GJBR= Global Journal of Business Research; IJCA = International Journal of Critical Accounting; IJEA= International Journal of Economics and Accounting; IJPSM= International Journal of Public Sector Management; IBER= International Business \& Economics Research Journal; JPS= Journal of Pacific Studies; $\mathrm{MA}=$ Master of Arts thesis; MAR= Management Accounting Research; PAR= Pacific Accounting Review; RAET = Research in Accounting in Emerging and Transition Economics. 


\section{References}

Alam, M., Lawrence, S., \& Nandan, R. (2004). Accounting for economic development in the context of post- colonialism: The Fijian experience. Critical Perspectives on Accounting, $15,135-157$.

Allawatage, C; Hopper, T. and Wickramasinghe, D. (2007). Guest editorial: Introduction to management accounting in less developed countries. Journal of Accounting and Organizational Change, vol.3 (3), pp.183-191

Brown, A. (2009a). The milieu of reporting of Nacamaki and Nabuna villages of Koro Island. Pacific Accounting Review, 21(3), 202-227.

Brown, A. M. (2009b). Reporting performance of Fiji public sector between the coups. Financial Reporting Regulation and Governance, 8(1), 1-31.

Chand, P. (2002). Relevance of International Accounting Standards in Developing Countries: The Case for the South Pacific Island Nations (MA). University of the South Pacific, Suva, Fiji.

Chand, P. (2005a). Impetus to the success of harmonisation: The case of South Pacific Island Nations. Critical Perspectives on Accounting, 16(3), 209-226.

Chand, P. (2005b). Convergence of accounting standards in the South Pacific island nations: The case of Fiji. Journal of Pacific Studies, 28(2), 269-290.

Chand , P., \& Patel, C. (2008). Convergence and harmonisation of accounting standards in the South Pacific region. Advances in Accounting, incorporating Advances in International Accounting, 24, 83-92.

Chand, P., Patel, C., \& Patel, A. (2010). Interpretation and application of "new" and "complex" international financial reporting standards in Fiji: Implications for convergence of accounting standards. Advances in Accounting, incorporating Advances in International Accounting, 26, 280-289.

Chand, P., \& White, M. (2007). A critique of the influence of globalization and convergence of accounting standards in Fiji. Critical Perspectives on Accounting, 18, 605-622.

Chand, P., \& White, M. (2006). The influence of culture on judgements of accountants in Fiji. Australian Accounting Review, 16(3), 82-88.

Davie, S. S. K. (2000a). The significance of ambiguity in accounting and everyday life: The selfperpetuation of accounting. Critical Perspectives on Accounting, 11, 311-334.

Davie, S. S. K. (2000b). Accounting for imperialism: A case of British-imposed indigenous collaboration. Accounting, Auditing and Accountability Journal, 13(3), 330-359.

Davie, S. S. K. (2004). Accounting and reform initiatives: Making sense of situation-specific resistance to accounting. Research in Accounting in Emerging and Transition Economies Supplement 2, 333-358.

Devi, S. S., Kumar, R. S., \& Raju, S. K. (2012a). Regulation of accounting firms: Evidence from Fiji. Global Journal of Business Research, 6(1), 91-101.

Devi, S. S., Kumar, R. S., \& Raju, S. K. (2012b). Partnering with practices for accounting education: Evidence from the Pacific. Business Education and Accreditation, 4(2), 61-72.

Hooper, T; Tsamenyi, M; Uddin, S. and Wickramasinghe, D. (2009). Management accounting in less developed countries: What is known and needs knowing, Accounting, Auditing and Accountability Journal, vol.25 (2), pp.295-327.

Hussain, F. F., Chand, P. V., \& Rani, P. (2012). The impact of IFRS for SMEs on the accounting profession: Evidence form Fiji. Accounting \& Taxation, 4(2), 107-118. 
Irvine, H., \& Deo, H. (2006). The power of the lens: A comparative analysis of two views of the Fiji Development Bank. Accounting, Auditing \& Accountability Journal, 19(2), 205-227.

Juchau, R. (1978). Accounting practice problems in Papua New Guinea and Fiji. Australian Accountant, 110-113.

Kapadia, K. J. (1980). The development of accounting profession in Fiji. Fiji Accountant, 15-19.

Kukereja, M. (1997). The development of accounting in Fiji. Fiji Accountant, 4-8.

Laughlin, R. (1991). Environmental disturbances and organizational transitions and transformations: Some alternative models. Organization Studies, 12(2), 209-232.

Lawrence, S., Sharma, U., \& Nandan, R. (2009). Giving institutional theory a critical edge: a study of systems change in a Fijian housing authority. International Journal of Critical Accounting, 1(4), 390- 405.

Lodhia, S. (1999). Environmental accounting in Fiji: An extended case study of the Fiji Sugar Corporation. Journal of Pacific Studies, 23(2), 283-309.

Lodhia, S. K., Burritt, R.L. (2004). Public sector accountability failure in an emerging economy the case of the National Bank of Fiji. The International Journal of Public Sector Management, 17(4), 345- 359.

Mala, R., \& White, M. (2009). The South Pacific Stock Exchange: Is it a market or status symbol. Australian Accounting Review, 19(1), 54-63.

Nandan, R. K., \& Alam, M. (2004). Changes in management control systems in a state-owned development Financial institution: Some evidence from Fiji. Research in Accounting in Emerging and Transition Economies Supplement 2, 305-331.

Nath, N., \& Sharma, U. (2014). Performance management systems in the public housing sector: Dissemination to diffusion. Australian Accounting Review, 24(1), 2-20.

Pathik, K. (2000). Extent of non-compliance with Fiji Accounting Standard. University of the South Pacific, Suva, Fiji.

Reddy, K., \& Sharma, U. (2011). Global corporate governance practices at crossroads: Lessons for Fiji. Fijian Studies: A Journal of Contemporary Fiji, 9(2), 53- 82.

Reddy, K., \& Sharma, U. (2014). Institutional antecedents of principal-based corporate governance practices: A case study of publicly listed companies in Fiji. Journal of Accounting \& Organizational Change, 10(1), 49-82.

Rika, N., Tuiseke, N., Tuiloa, M., \& Finau-Tavite, S. (2008). Accounting and accountability by provincial councils in Fiji: The case of Namosi. Australasian Accounting Business and Finance Journal, 2(1), 15-35.

Shailer, G. E. P., \& Vatuloka, E. (2000). Preferences for the regulation and monitoring of Fijian government and accounting. Asian Review of Accounting, 8(2), 102-125.

Sharma, U., \& Davey, H. (2013). Voluntary disclosure in the annual reports of Fijian companies. International Journal of Economics and Accounting, 4(2), 184-208.

Sharma, U., \& Hoque, Z. (2002). TQM implementation in a public sector entity in Fiji: Public sector reform, commercialisation and institutionalisation. The International Journal of Public Sector Management, 15(5), 340- 360.

Sharma, U., \& Lawrence, S. (2005). Public sector reform, global trends vs local needs: The case of a state rental organisation in Fiji. Journal of Accounting \& Organizational Change, 1(2), 141-164.

Sharma, U., \& Lawrence, S. (2008). Stability and change at FPTL: An institutional perspective. Australian Accounting Review, 18(1), 25-34. 
Sharma, U., \& Lawrence, S. (2009). Global remedies for local needs: Corporate governance and public sector reforms in Fiji. Pacific Accounting Review, 21(3), 260- 285.

Sharma, U., Lawrence, S., \& Fowler, C. (2012). New public management and accounting in a Fiji telecommunications company. Accounting History, 17(3-4), 331-348.

Sharma, U., Lawrence, S., \& Lowe, A. (2010). Institutional contradiction and management control innovation: A field study of total quality management practices in a privatized telecommunication company. Management Accounting Research, 21(4), 251-264.

Sharma, U., Low, R., \& Davey, H. (2013). Developments in non-monetary disclosures in annual reports of companies: A case study. International Journal of Economics and Accounting, 4(4), 297-326.

Tickell, G. (2010). Cash to accrual accounting: One nation's dilemma. International Business \& Economics Research Journal, 9(11), 71-78.

White, M. (2005). Returns from Fiji National Provident Fund: accounting myth vs. economic reality. Fijian Studies, 3(1), 1- 20. 